L. Blonskaya, L. Ishbirdina, A. Gabdelkhakov

\title{
GROWTH OF THE BASHKIR PYRAMIDAL POPLAR (POPULUS NIGRA F. PYRAMIDÁLIS) IN THE PROTECTIVE TREE STANDS OF THE PRE-URALS
}

Key words: Bashkir pyramidal poplar; growth; lateral shoot; age class; crown; decorative features; sanitary and hygienic properties.

\section{Authors' personal details}

1. Lyubov' Blonskaya, Candidate of Biological Sciences, Associate Professor, Associate Professor of the Department of Forestry and Landscape Design, Federal State Budgetary Educational Institution of Higher Education «Bashkir State Agrarian University», 450001, Ufa, 50-letiya Oktyabrya St., 34, e-mail: 1.n.blonskaya@mail.ru.

2. Liliya Ishbirdina, Candidate of Biological Sciences, Associate Professor, Associate Professor of the Department of Forestry and Landscape Design, Federal State Budgetary Educational Institution of Higher Education «Bashkir State Agrarian University», 450001, Ufa, 50-letiya Oktyabrya St., 34, e-mail: butomus1 1 @yandex.ru.

3. Aidar Gabdelkhakov, Candidate of Agricultural Sciences, Associate Professor of the Department of Forestry and Landscape Design, Federal State Budgetary Educational Institution of Higher Education «Bashkir State Agrarian University», 450001, Ufa, 50-letiya Oktyabrya St., 34, e-mail: aliya201199@mail.ru.

Large industrial cities face specific and mostly unfavourable environmental conditions for human life and activities. Adequately arranged green spaces in the city are intended for decorative and protective purposes. The practice reduces the negative impact of the urban factors on people considerably. The Populus L. species demonstrate the best potential for improving the environmental conditions in the industrial centres. The growth of lateral shoots is crucial in the development of the tree's aesthetic and sanitary-hygiene features. Lateral shoots form a dense columnar crown. The shape is a rare case in deciduous trees growing in the region's nat- ural and climatic conditions. The hybrid poplar stands (Populusnigra L. $\times$ Populusnigra f. ItalicaDuroi) act as buffer zones between cities and surrounding natural and agricultural ecosystems. They act as a green filter against industrial pollutants and create highly decorative alleys and row plantings. The paper analyses the seasonal dynamics of the lateral shoots' growth in the Bashkir pyramidal poplar found in the green spaces of the Pre-Ural cities such as Ufa, Tuimazy, and Kumertau. The study found the average of the annual lateral shoot growth in the poplar. The value depended on the growing season and anthropogenic factors in each of the cities.

(с) Блонская Л.Н., Ишбирдина Л.М., Габделхаков А.К.

УДК 633.8

DOI: $10.31563 / 1684-7628-2020-56-4-26-32$

Е.С. Васфилова

\section{НЕКОТОРЫЕ ПЕРСПЕКТИВНЫЕ ЛЕКАРСТВЕННЫЕ РАСТЕНИЯ В УСЛОВИЯХ ИНТРОДУКЦИИ НА СРЕДНЕМ УРАЛЕ}

\section{Ключевые слова: лекарственные растения; интродукция растений; Средний Урал.}

Введение. Лекарственные растения являются экономически важной группой видов. Для полноценного использования их в медицине необходимо, наряду с достаточным содержанием биологически активных веществ и доказанным фармакологическим действием, наличие обеспеченной сырьевой базы. Она может формироваться как путем заготовок лекарственного растительного сырья (ЛРС) в природных условиях, так и путем культивирования лекарственных растений. При этом их выращивание в контролируемых условиях имеет определенные преимущества перед заготовкой в природе, т. к. в ряде случаев способствует улучшению каче- 
ства растительного сырья (повышенному накоплению действующих веществ). Кроме того, переход к возделыванию ценных видов растений позволит весьма существенно снизить нагрузку на их природные популяции, что особенно важно для территорий с высоким уровнем антропогенного воздействия на природную среду. К таким территориям относится, в частности, Средний Урал.

С конца прошлого столетия в России произошло резкое снижение (в несколько раз) объема производства лекарственного растительного сырья. В то же время наблюдается устойчивая тенденция повышения спроса на него и натуральные виды продукции [1]. Около 40 \% препаратов, представленных на отечественном фармацевтическом рынке, производятся из ЛРС. Кроме предприятий здравоохранения и химикофармацевтической промышленности, покупателями ЛРС являются производители парфюмерно-косметической продукции, парафармацевтиков (БАДы), пищевых красителей и др. Однако заготовка дикорастущих растений в стране резко сократилась, а отечественные производители выращивают только 15-20 видов лекарственных растений [1]. В этих условиях изучение возможностей выращивания различных видов лекарственных растений в разных регионах приобретает большое значение.

В Уральском регионе лекарственное растениеводство развито очень слабо. Между тем, природно-климатические условия позволяют выращивать здесь ряд ценных видов. Увеличение сырьевой базы и расширение ассортимента возделываемых лекарственных растений с целью получения лекарственного сырья с разнообразными видами фармакологического действия является актуальным для Уральского региона. В условиях Ботанического сада Уральского отделения РАН (Средний Урал, г. Екатеринбург) на протяжении ряда лет изучались особенности интродукции различных видов лекарственных растений, и довольно многие из них оказались весьма перспективными.

Цель исследования - анализ итогов интродукции некоторых видов лекарственных растений с точки зрения их перспективности для выращивания на Среднем Урале.

Условия, материалы и методы исследования. Ботанический сад УрО РАН находится в подзоне южной тайги. Климат умеренно-континентальный, с суровыми зимами и коротким летом, характерна сильная изменчивость погодных условий, хорошо выражены сезоны года. Среднегодовая температура $+1,0{ }^{\circ} \mathrm{C}$, длительность безморозного периода 100-105 дней.
Средняя температура самого холодного месяца (января) составляет $-15,3^{\circ} \mathrm{C}$, самого теплого месяца (июля) $+17,4^{\circ} \mathrm{C}$. Количество осадков за год -458 мм [2].

В условиях интродукции изучались официнальные виды, т. е. виды, используемые в научной медицине России (входящие в «Государственный реестр лекарственных средств» $[3,4]$ и в «Государственную фармакопею Российской федерации» [5]): арника Шамиссо, коровяк густоцветковый, большеголовник сафлоровидный, синюха голубая. Кроме того, изучены виды, не используемые в научной медицине России (неофицинальные), но широко применяемые в народной медицине, а также в медицине других стран: володушка золотистая, тимьян блошницевидный (яйцевидный). Период наблюдений для отдельного вида составлял от 20 до 35 лет.

Наблюдения за сезонным ростом и развитием растений проводили по методике Главного ботанического сада РАН [6]: отмечали начало весеннего отрастания (или возобновления роста у зимнезеленых видов), бутонизации, начало и конец цветения, начало созревания плодов, отмирание генеративных побегов, полное отмирание надземной части. Интродукционную перспективность вида определяли по 6 показателям, каждый из которых оценивали по трехбалльной шкале (от 1 до 3 баллов) [7]: семенное размножение и самосев; естественное вегетативное размножение в условиях культуры; мощность развития растений (высота особей, размеры побегов и листьев) по сравнению с естественными условиями обитания; устойчивость к поражению вредителями и болезнями; зимостойкость; длительность существования вида в условиях интродукции. В результате суммирования баллов по всем показателям получали общую оценку перспективности интродукции. Однако непосредственно этот показатель не использовали, т. к. в интродукционный эксперимент вовлекались не только многолетники, но также и двулетник (коровяк густоцветковый), у которого отсутствовало вегетативное размножение. В связи с этим суммарную оценку делили на число изучавшихся показателей (6-у многолетников, 5 - у двулетника) и получали средний балл интродукционной перспективности, который применяли для оценки успешности интродукции; его величина, таким образом, могла варьировать в пределах от 1 до 3.

Результаты исследования. В ходе работы изучены особенности роста и развития в условиях интродукции в подзону южной тайги ряда растений научной медицины России. 
Арника Шамиссо - Arnica chamissonis Less., травянистый многолетник североамериканского происхождения. Цветки арники обладают бактерицидным, противовоспалительным и кровоостанавливающим действием, применяются для лечения инфицированных ран, ушибов, ожогов, обморожений и т. п.; используются при различных внутренних кровотечениях (маточных, геморроидальных, желудочно-кишечных), в акушерско-гинекологической практике; применяются как желчегонное средство, а также при стенокардии [8].

В условиях Среднего Урала отрастание надземных побегов происходит в конце апреля первой половине мая. Цветение начинается в конце июня - начале июля и длится полтора-два месяца. Зрелые семена появляются с начала августа. Плодоношение хорошее, но самосев слабый. При этом лабораторная всхожесть семян после сухого хранения в течение шести месяцев при комнатной температуре составляла $70 \%$. Вид прекрасно размножается вегетативно. Длина генеративных побегов варьирует от шестидесяти до 80 сантиметров (таблица 1). Надземная часть отмирает в первой половине середине октября. Длительность жизни отдельной особи составляет около десяти лет. Для растений характерна высокая зимостойкость. Вредителями и болезнями они не поражаются (таблица 2).

Таблица 1 Морфологические показатели изученных видов в условиях интродукции на Среднем Урале*

\begin{tabular}{|l|c|c|c|c|c|c|}
\hline \multicolumn{1}{|c|}{ Вид } & $\begin{array}{c}\text { Число генера- } \\
\text { тивных побегов } \\
\text { у особи }\end{array}$ & $\begin{array}{c}\text { Длина } \\
\text { генеративного } \\
\text { побега, см }\end{array}$ & $\begin{array}{c}\text { Число } \\
\text { стеблевых } \\
\text { листьев }\end{array}$ & $\begin{array}{c}\text { Длина стеблевого } \\
\text { листа в средней } \\
\text { части побега, см }\end{array}$ & $\begin{array}{c}\text { Длина верху- } \\
\text { шечного со- } \\
\text { цветия, см }\end{array}$ & $\begin{array}{c}\text { Диаметр } \\
\text { цветка, мм }\end{array}$ \\
\hline Арника Шамиссо & $1,7 \pm 0,3$ & $68,5 \pm 2,0$ & $19,2 \pm 0,4$ & $11,1 \pm 0,3$ & $1,9 \pm 0,03$ & - \\
\hline Коровяк густоцветковый & $1,3 \pm 0,3$ & $111,4 \pm 3,9$ & $222,2 \pm 1,9$ & $11,3 \pm 0,6$ & $26,6 \pm 4,1 * *$ & $20,0 \pm 1,1$ \\
\hline Рапонтикум сафлоровидный & $1,6 \pm 0,2$ & $141,7 \pm 4,0$ & $29,3 \pm 8,2$ & $27,1 \pm 3,9$ & $4,4 \pm 0,2$ & - \\
\hline Синюха голубая & $9,5 \pm 1,7$ & $102,7 \pm 1,7$ & $25,5 \pm 0,9$ & $18,8 \pm 0,6$ & $14,5 \pm 1,1 * *$ & $29,3 \pm 0,5$ \\
\hline Володушка золотистая & $2,4 \pm 0,4$ & $94,2 \pm 5,1$ & $9,9 \pm 0,4$ & $19,2 \pm 0,8$ & $3,6 \pm 0,2$ & $19,5 \pm 0,5$ \\
\hline Тимьян блошницевидный & - -*** & $26,2 \pm 0,2$ & $23,6 \pm 0,2$ & $1,3 \pm 0,2$ & $2,5 \pm 0,3$ & $3,0 \pm 0,2$ \\
\hline
\end{tabular}

* Приведены средние значения признаков и ошибки средних.

** У коровяка густоцветкового и синюхи голубой приведена длина всей генеративной части побега.

*** У тимьян блошницевидного этот показатель не определяли в связи со сложностью разграничения отдельных особей изза интенсивного вегетативного размножения.

Таблица 2 Перспективность интродукции в условия Среднего Урала видов, используемых в научной медицине России (в баллах)

\begin{tabular}{|l|c|c|c|c|c|c|c|}
\hline \multicolumn{1}{|c|}{ Вид } & $\begin{array}{c}\text { Семенное } \\
\text { возобновле- } \\
\text { ние }\end{array}$ & $\begin{array}{c}\text { Вегетатив- } \\
\text { ное возоб- } \\
\text { новление }\end{array}$ & $\begin{array}{c}\text { Мощность } \\
\text { развития } \\
\text { растений }\end{array}$ & $\begin{array}{c}\text { Устойчивость } \\
\text { к поражению } \\
\text { вредителями } \\
\text { и болезнями }\end{array}$ & $\begin{array}{c}\text { Зимо- } \\
\text { стой- } \\
\text { кость }\end{array}$ & $\begin{array}{c}\text { Длительность } \\
\text { существова- } \\
\text { ния в усло- } \\
\text { виях культуры }\end{array}$ & $\begin{array}{c}\text { Средний перспек- } \\
\text { тивности ин- } \\
\text { тродукции }\end{array}$ \\
\hline Арника Шамиссо & 2 & 3 & 2 & 3 & 3 & 3 & 2,67 \\
\hline Коровяк густоцветковый & 2 & - & 3 & 3 & 3 & 3 & 2,8 \\
\hline Рапонтикум сафлоровидный & 2 & 2 & 2 & 3 & 3 & 3 & 2,5 \\
\hline Синюха голубая & 3 & 1 & 3 & 3 & 3 & 3 & 2,67 \\
\hline
\end{tabular}

Коровяк густоиветковый - Verbascum densiflorum Bertol. Двулетнее растение, европейский вид. Цветки (венчики с приросшими к ним тычинками) используют в научной медицине и гомеопатии многих стран мира. Это эффективное отхаркивающее, обволакивающее и мягчительное средство при заболеваниях верхних дыхательных путей (ларингите, фарингите, бронхите и т. д.), а также вяжущее средство $[8,9]$. Отмечена противовирусная активность цветков коровяка [10]. Они используются для приготовления водного настоя, в составе грудных сборов. Цветки близкого вида - коровяка обыкновенного входят в состав бальзама Биттнера, применяющегося как общеукрепляющее и иммуномодулирующее лекарственное средство. Сырье коровяка имеет экспортное значение [4].
В условиях Ботанического сада УрО РАН у коровяка густоцветкового часто наблюдаются зимующие розетки листьев. Рост новых надземных побегов начинается в конце апреля - первой половине мая. Цветение длительное, с июля до октября. Семена созревают в конце августа - сентябре. Самосев обычно хороший, но в отдельные годы бывает слабым. Вегетативное размножение отсутствует. Растения крупнее, чем в природных условиях. К концу цветения генеративные побеги полегают, их полное отмирание происходит к концу октября. Болезнями и вредителями вид не повреждается, зимует хорошо (таблица 2).

Большеголовник (рапонтикум) сафлоровидный (левзея сафлоровидная) - Rhaponticum carthamoides (Willd.) Iljin, травянистое многолетнее растение, эндемик Южной Сибири 
(Алтай, Саяны), ареал на востоке доходит до озера Байкал. Редкий вид, занесен в «Красную книгу Российской федерации» [11]. Корневища с корнями растений этого вида оказывают тонизирующее действие; повышают умственную и физическую работоспособность; способствуют усилению процессов синтеза белка в организме (анаболическое действие), что имеет значение для применения в спортивной медицине. Сырье также может использоваться для производства тонизирующих напитков $[4,9]$.

Весеннее отрастание побегов начинается в конце апреля - начале мая. Цветение короткое, в течение двух - трех недель, в июне. Семена созревают быстро, в конце июня - начале июля. Самосев отсутствует. В целом, цветение и плодоношение в Ботаническом саду УрО РАН происходит раньше, чем в природных условиях. Лабораторная всхожесть семян после восьми месяцев сухого хранения при комнатной температуре составляла 7-10\%; семена нуждаются в предпосевной стратификации, либо посеве под зиму. Растения хорошо размножаются вегетативно, путем деления сильно разрастающихся корневищ. Длина генеративных побегов варьирует от одного до полутора метров (таблица 1). Вредителями и болезнями растения мало поражаются, в отдельные годы отмечалось повреждение листьев листогрызущими насекомыми. Зимостойкость высокая (таблица 2).

Синюха голубая - Polemonium caeruleum L., травянистый многолетник. Произрастает в лесной и лесостепной зонах европейской части России, Урала, Западной Сибири. Не образует зарослей, пригодных для массового сбора сырья. Заготовка дикорастущих растений весьма трудоемка. В 1970-80-х гг. вид культивировался в СССР (в Белоруссии) [9]. В настоящее время практически не возделывается.

Синюха голубая явно недооценена, поскольку используется в настоящее время слабо, но при этом обладает широким спектром фармакологического действия. Корневища с корнями оказывают седативное действие на центральную нервную систему, сопоставимое с действием сырья валерианы. Они обладают гипотензивными свойствами, могут использоваться при кардионеврозах, стенокардии и т. п. [4]. Кроме того, сырье синюхи обладает выраженным отхаркивающим действием, применяется при острых и хронических бронхитах, бронхопневмониях, абсцессах легких; эффективно при лечении язвенной болезни желудка и двенадцатиперстной кишки. Есть данные о противоопухолевых свойствах корневищ с корнями синюхи [10]. Сырье используется в виде отвара; входит в состав фиточаев и некоторых БАД.
В условиях интродукции на Среднем Урале растения часто зимуют с зелеными листьями. Возобновление роста побегов происходит рано, во второй половине апреля. Цветение наблюдается в первой половине лета, с конца мая - начала июня до середины июля. В отдельные годы отмечалась вторая волна цветения, в августе - начале сентября. Плодоношение обильное, с конца июня - начала июля, иногда с середины июня. Самосев интенсивный, на расстоянии до пяти - шести метров от исходной гряды. Всхожесть семян после пяти месяцев сухого хранения при комнатной температуре составляла 42-58 \%. Вегетативно естественным путем растения не размножаются, но их можно размножать искусственно, делением корневищ. Длина генеративных побегов варьирует от 0,9 до 1,1 метров (таблица 1 ), иногда наблюдается полегание побегов. Надземная часть отмирает в сентябре. Вид отличается высокой зимостойкостью и устойчивостью к болезням и вредителям (таблица 2).

Кроме видов научной медицины, в Ботаническом саду Уро РАН изучены перспективные растения народной медицины.

Володушка золотистая - Bupleurum aureum Fisch. ex Hoffm. Травянистый многолетник, распространен на востоке европейской территории России, в Западной и Восточной Сибири. В народной медицине надземная часть растений широко используется как желчегонное средство при болезнях печени и желчного пузыря, стимулирует выделение желудочного сока и повышает его кислотность, проявляет противоопухолевую активность. Есть указания на адаптогенные свойства данного вида [12]. Химический состав и биологическая активность видов володушки подробно изучались в Центральном Сибирском ботаническом саду (Новосибирск) [13]. Изучение элементного состава надземной части этого вида подтвердило безопасность ее применения в медицине [14]. В настоящее время в России производится ряд биологически активных добавок на основе сырья володушки золотистой (фиточаи, порошки, измельченное сырье) [15].

Надземные побеги в условиях интродукции на Среднем Урале начинают отрастать во второй половине апреля - начале мая. Растения цветут с середины июня до конца июля - начала августа. Зрелые семена появляются в начале - середине августа. Цветение и плодоношение обильное, отмечается хороший самосев. Длина генеративных побегов варьирует от 0,8 до 1,4 метра (таблица 1), иногда они могут полегать. Отмирание надземной части происходит в начале октября. Продолжительность жизни отдельной 
особи составляет шесть - восемь лет. Для вида характерна высокая зимостойкость, устойчивость к болезням и вредителям (таблица 3 ).

Тимьян блошницевидный (Т. яйцевидный) - Thymus pulegioides L. (T. ovatus Mill.). Полукустарничек, европейский вид. Трава (надземные цветущие побеги) обладает выраженным отхаркивающим действием, близким к действию травы тимьянов ползучего (чабреца) и тимьяна обыкновенного, используемых в научной медицине России [16]. Но тимьян ползучий заготавливается только в природных условиях, а тимьян обыкновенный - средиземноморский вид, очень требовательный к теплу, потребность в его сырье не удовлетворяется [4]. Благодаря высокому содержанию эфирного масла, тимьян блошницевидный может использоваться как пряность, подобно другим видам тимьянов [17].
Вид обладает выраженными декоративными свойствами, может использоваться как почвопокровное растение.

Растения зимнезеленые. В наших условиях весенний рост новых побегов начинается в конце апреля - начале мая. Цветение обильное и продолжительное, в июле - сентябре, иногда затягивается до середины октября. Начало и конец цветения в условиях культуры наступают немного позже, чем в природных условиях. Плодоношение начинается в конце августа - начале сентября; наблюдается обильный самосев. Растения хорошо размножаются вегетативно. Длина надземных побегов варьирует от пятнадцати до тридцати сантиметров (таблица 1). Растения высоко устойчивы к поражениям болезнями и вредителями, засухоустойчивы, отличаются высокой зимостойкостью (таблица 3).

Таблица 3 Результаты интродукции в условия Среднего Урала перспективных неофицинальных видов лекарственных растений (в баллах)

\begin{tabular}{|c|c|c|c|c|c|c|c|}
\hline Вид & $\begin{array}{c}\text { Семенное } \\
\text { возобновле- } \\
\text { ние }\end{array}$ & $\begin{array}{c}\text { Вегетативное } \\
\text { возобновле- } \\
\text { ние }\end{array}$ & $\begin{array}{c}\text { Мощность } \\
\text { развития } \\
\text { растений }\end{array}$ & $\begin{array}{c}\text { Устойчивость } \\
\text { к поражению } \\
\text { вредителями } \\
\text { и болезнями }\end{array}$ & $\begin{array}{c}\text { Зимо- } \\
\text { стойкость }\end{array}$ & $\begin{array}{c}\text { длительность } \\
\text { суествования } \\
\text { в условиях } \\
\text { культуры }\end{array}$ & $\begin{array}{c}\text { Средний балл } \\
\text { перспектив- } \\
\text { ности интро- } \\
\text { дукции }\end{array}$ \\
\hline $\begin{array}{c}\text { Володушка } \\
\text { золотистая }\end{array}$ & 3 & 2 & 2 & 3 & 3 & 3 & 2,67 \\
\hline $\begin{array}{c}\text { Тимьян } \\
\text { блошницевидный }\end{array}$ & 3 & 3 & 2 & 3 & 3 & 3 & 2,83 \\
\hline
\end{tabular}

Выводы. Анализ итогов интродукции некоторых лекарственных растений в условия Среднего Урала показал высокую перспективность для возделывания в данном регионе видов научной медицины (официнальных) - арники Шамиссо, коровяка густоцветкового, большеголовника сафлоровидного, синюхи голубой. Сырье этих видов используется для приготовления различных лекарственных форм (настоев, отваров, настоек и т. д.). Сырье большеголовника, кроме того, представляет интерес для пищевой промышленности (производство тонизирующих напитков).

Представляет интерес выращивание перспективных неофицинальных видов - володушки золотистой и тимьяна блошницевидного (яйцевидного). Трава (надземная часть) растений данных видов может использоваться для приготовления настоев и производства биологически активных добавок. В настоящее время сырье володушки в небольшом количестве уже присутствует в аптеках Уральского региона. Тимьян блошницевидный, помимо использования с лечебными целями, может найти применение в пищевой промышленности и в цветоводстве. Изученные виды являются перспективными для возделывания в местных природно-климатических условиях.

Работа выполнена в рамках государственного задания Ботанического сада УрО РАН "Теоретические и методологические аспекты изучения и оценки адаптации интродуцированных растений природной и культурной флорыl», номер государственной регистращии АAАAA17-117072810010-4.

\section{Библиографический список}

1. Куркин, В.А. Фармакогнозия [Текст]/ В.А. Куркин. Самара: Офорт; СамГУ Росздрава, 2007. $1239 \mathrm{c}$.

2. Климат Свердловска [Текст]. Л.: Гидрометеоиздат, $1981.191 \mathrm{c.}$

3. Государственный реестр лекарственных средств [Электронный ресурс]. Режим доступа: http://grls.rosminzdrav.ru/grls.aspx.
4. Фармакогнозия. Лекарственное сырьё растительного и животного происхождения [Текст] / Под ред. Г.П. Яковлева. СПб.: СпецЛит, 2013.848 с.

5. Государственная Фармакопея Российской Федерации [Электронный ресурс]. XIV издание. 2018. T. 4. Режим доступа: http://femb.ru/ femb/pharmacopea.php. 
6. Методика фенологических наблюдений в ботанических садах СССР [Текст] // Бюллетень Главного ботанического сада РАН. 1979. Вып. 113. С. 3-8.

7. Васфилова, Е.С. Взаимосвязь жизненных форм растений с результатами их интродукции в новые условия среды [Текст] / Е.С. Васфилова // Вестник Воронежского государственного университета. Серия: Химия. Биология. Фармация. 2018. № 2. С. 94-104.

8. Ловкова, М.Я. Почему растения лечат [Текст] / М.Я. Ловкова, А.М. Рабинович, С.М. Пономарева, Г.Н. Бузук, С.М. Соколова. М.: Наука, 1989. 256 с.

9. Атлас лекарственных растений России [Текст]. М., 2006. 345 с.

10. Растительные ресурсы России: дикорастущие цветковые растения, их компонентный состав и биологическая активность. Т. 4 [Текст] / Отв. ред. А.Л. Буданцев. СПб.; М.: Товарищество научных изданий КМК, 2011. 630 с.

11. Красная книга Российской Федерации (Растения и грибы) [Текст]. М.: Товарищество научных изданий КМК, 2008. 855 с.

12. Бабий, Н.В. Особенности проектирования тонизирующих напитков для повышения ре- зистентности организма [Текст] / Н.В. Бабий, В.А. Помозова, Д.Б. Пеков // Техника и технология пищевых производств. 2016. Т. 41. № 2. C. $13-20$.

13. Минаева, В.Г. Лекарственные растения Сибири [Текст] / В.Г. Минаева. Новосибирск: Наука; Сиб. отделение, 1991. 431 с.

14. Зыкова, И.Д. Изучение компонентного состава эфирного масла и минерального состава володушки золотистой Сибирского региона [Текст] / И.Д. Зыкова, А.А. Ефремов // Химия растительного сырья. 2013. № 1. С. 119-124.

15. Регистр лекарственных средств России [Электронный ресурс]. Режим доступа: https:// www.rlsnet.ru/search result.htm?word $=\% \mathrm{E} 2 \%$ EE \%EB \%EE \%E4 \%F3 \%F8 \%EA \%E0\&path= $\% 2 \mathrm{~F} \&$ enter_clicked $=1 \&$ letters $=$.

16. Бубенчикова, В.Н. Изучение отхаркивающей активности растений рода Тимьян [Текст] / В.Н. Бубенчикова, Ю.А. Старчак // Медицинский вестник Башкортостана. 2013. № 5. С. $78-$ 80.

17. Машанов, В.И. Пряноароматические растения [Текст] / В.И. Машанов, А.А. Покровский. М.: Агропромиздат, 1991. 287 с.

\section{Сведения об авторе}

Васфилова Евгения Самуиловна, кандидат биологических наук, доцент, старший научный сотрудник лаборатории интродукции травянистых растений, Ботанический сад УрО РАН, 620144, г. Екатеринбург, ул. 8 Марта, 202a, e-mail: euvas@mail.ru.

Увеличение сырьевой базы и расширение ассортимента возделываемых лекарственных растений для получения лекарственного сырья с разнообразным фармакологическим действием является актуальным для Уральского региона. Цель исследования - анализ итогов интродукции некоторых видов лекарственных растений в Ботаническом саду Уральского отделения Российской Академии наук (Екатеринбург) с точки зрения их перспективности для выращивания на Среднем Урале. Интродукционную перспективность вида определяли по шести показателям: семенное размножение и самосев; естественное вегетативное размножение; мощность развития растений (высота особей, размеры побегов и листьев); устойчивость к вредителям и болезням; зимостойкость; длительность существования в условиях интродукции. Анализ результатов интродукции показал высокую перспективность для возделывания в данном регионе видов научной медицины - арники Шамиссо (Arnica chamissonis Less.), коровяка густоцветкового (Verbascum densiflorum Bertol.), большеголовника сафлоровидного (Rhaponticum carthamoides (Willd.)
Iljin), синюхи голубой (Polemonium caeruleum L.). Сырье этих видов используется для приготовления различных лекарственных форм; сырье большеголовника может использоваться и для производства тонизирующих напитков. Для этих видов характерно устойчивое плодоношение, синюха и коровяк дают обильный самосев, арника хорошо размножается вегетативно. Виды высокозимостойки, вредителями и болезнями не поражаются, накапливают значительную фитомассу. Представляет также интерес выращивание неофицинальных видов - володушки золотистой (Bupleurum aureum Fisch. ex Hoffm.), тимьяна блошницевидного (Thymus pulegioides L.). Надземная часть данных видов может применяться для приготовления настоев и производства биологически активных добавок. Тимьян блошницевидный, кроме использования в медицине, может применяться в пищевой промышленности и цветоводстве. Изученные виды являются перспективными для возделывания в местных природно-климатических условиях. 
PROMISING MEDICINAL PLANTS INTRODUCED INTO THE MIDDLE URALS

\author{
Key words: medicinal plants; plant introduction; Middle Urals.
}

\title{
Authors' personal details
}

Evgeniya Vasfilova, Candidate of Biological Sciences, Associate Professor, Senior Researcher of the Herbaceous Plant Introduction Laboratory, Botanical Garden of the Ural Branch of the Russian Academy of Sciences, 620144, Yekaterinburg, 8 Marta st., 202A, e-mail: euvas@mail.ru.

Increasing the raw material base and expanding the range of cultivated medicinal plants for obtaining medicinal raw materials with an array of pharmacological effects is critical for the Ural region. The study aimed to analyse some medicinal plants' introduction into the Botanical garden of the Ural Branch of the Russian Academy of Sciences (Yekaterinburg) in terms of their prospects for growth in the Middle Urals. The following six indicators were used to establish the species' introduction potential: seed propagation and self-seeding; natural vegetative reproduction; plant development capacity (the plant height, size of shoots and leaves); resistance to pests and diseases; winter hardiness; life extent under introduction. The analysis showed a high potential for the cultivation of the following medicinal plants in the region: Chamisso arnica (Arnica chamissonis Less.), densely flowered mullein (Verbascum densiflorum Bertol.), Maral root (Rhaponticum

(C) Васфилова Е.С. carthamoides (Willd.) Iljin), Greek valerian (Polemonium caeruleum $\mathrm{L}$.). The plants are used as a raw material for the preparation of various dosage forms; for example, the Maral root is also used to produce soft drinks. The species demonstrate stable fruitification. Densely flowered mullein and Greek valerian show abundant self-seeding, Chamisso arnica has useful vegetative reproduction features. The plants are winter hardy, resistant to pests and diseases, and accumulate substantial phytomass. Cultivation of unofficial plants such as Bupleurum aureum Fisch. ex Hoffm., flea thyme (Thymus pulegioides L.) is also of interest. The aboveground part of these plants can be used for infusions and biologically active additives. The thyme flea can also be used in the food industry and flower growing. The species are reported promising for cultivation in the local environmental conditions.

УДК $577.21+582.632 .2$

DOI: $10.31563 / 1684-7628-2020-56-4-32-36$

Б. Деген, Ю. А. Янбаев, Р.Ю. Янбаев, С.Ю. Бахтина, А.А. Габитова, А.А. Тагирова

\section{ГЕНЕТИЧЕСКАЯ ИЗМЕНЧИВОСТЬ ДУБА ЧЕРЕШЧАТОГО В ПРИРОДНЫХ ПОПУЛЯЦИЯХ РАЗНОГО ПРОИСХОЖДЕНИЯ}

\section{Ключевые слова: дуб черешчатый; рефугиум; популяция; генетическая изменчивость.}

Введение. Дуб черешчатый (Quercus robur L.) относится к древесным растениям, наиболее важным в экономическом и экологическом отношениях. В условиях России состояние его насаждений в последние столетия существенно ухудшилось из-за неблагоприятных климатических факторов, сельскохозяйственного освоения лесной и лесостепной зон [2], нерациональных вырубок, энтомологических и фитопатологических причин [1]. Для выявления генетических последствий этого процесса актуальной и практически важной научной задачей является изучение генофонда популяций и выявление уровня их генетической изменчивости, определяющего потенциал для адаптации и выживаемости вида в целом [6]. Быстрое развитие молекулярно-генетических методов и особенно появление технологий секвенирования ДНК нового поколения [11] позволяют осуществлять эту работу на принципиально новом уровне. Недавно для исследования дуба черешчатого по всему ареалу вида был разработан новый набор локусов однонуклеотидных полиморфизмов [7], который применен в настоящем исследовании. 